\title{
Remote art centres and Indigenous development
}

\author{
Susan Congreve* AND John Burgess**
}

\begin{abstract}
Art centres fulfil many functions in remote regions as a source of Indigenous identity and creativity; as a link to the global art market; as centres for community engagement and participation; and as a source of social capital providing a range of services for local communities. They are dependent on funding from State and Federal authorities and they are identified as one of the success stories in remote community development. However, they face an uncertain future in the light of their multiple functions and their position as both a source of traditional identity and a link to an external art market. The article highlights the challenges faced by government in the evaluation of their effectiveness and contribution; and in particular discusses the suitability of the hybrid economy model as a representation of their functions.
\end{abstract}

Keywords: Australia, historical analysis, interpretivism, role of local cultures

Received 20 June 2017. Accepted 1 November 2017

\section{INTRODUCTION}

\begin{abstract}
A rt centres across regional and remote Australia support the contemporary cultural expression of more than 14,000 Aboriginal and Torres Strait Islander artists and are a significant part of remote local economies (Altman, 2012; Acker \& Woodhead, 2014a). These small enterprises fulfil a range of artistic, commercial, civic and social welfare functions, which places many of them under pressure to meet a range of community needs and expectations well beyond their scope as art producers (Wright, 1999). Art centres, like other businesses in remote Australia, are limited in size and scope because of their location and offer most artists only a small and irregular income stream. However, the services they provide are invaluable in development terms and are essential to future capacity building in communities with few employment alternatives.
\end{abstract}

Government policies and programmes have been determining factors in the success of remote art centres (Altman, 2013). The hopes of policymakers, politicians and government staff rest on the art centres as vehicles for economic engagement and independence for Aboriginal and Torres Strait Islander peoples (Minister for the Environment, Heritage and the Arts, 2008). Within this context, remote art centres are enmeshed in the debate about appropriate development strategies for remote communities and Aboriginal and Torres Strait Islander peoples, a debate which has political and theoretical affinities with international discussions in a developed and Third World context (Escobar, 1995). Art centres act as brokering institutions that link local economies to the global economy and champion cultural

* Jingili, Northern Territory, Australia

** College of Business, RMIT University, Melbourne, Australia

Corresponding author: john.burgess@rmit.edu.au 
difference. It is useful to see art centres within a development context, as this highlights the externally imposed transformative agenda and permits examination of how art centres are positioned theoretically in policy and programmes as well as practically in terms of how they operate. The gap between government discourse and development practice is the space within which the role and capacity of art centres in communities is contested.

The relationships between settler societies and Aboriginal and Torres Strait Islander people have been described by researchers as forms of 'internal colonialism' (Hechter, 1975; Beckett, 1987). In this relational frontier, Aboriginal and Torres Strait Islander people both participate in institutions in order to strengthen their sense of identity and are subject to the same institutions as vehicles of acculturation (Beckett, 1987; Escobar, 1995; Blagg, 2008). As a response to this tension, the hybrid economy concept has been proposed as a framework for better understanding local economies in remote communities (Altman, 2007). This model helps clarify how the customary, state and market domains interact, however, the value of the framework as a solution for economic marginalisation requires further investigation.

The purpose of this paper is to map the development of remote regional art centres; set out the range of competing objectives and aspirations linked to art centres; assess the hybrid economy model as a representation of the function of art centres; and consider the challenges remote art centres face in their continued development. The paper reviews secondary evidence and builds on the experience of the primary investigator in working with remote regional art centres (Congreve, 2016). The paper highlights the paradoxical and conflicting roles of art centres. As guardians of tradition and as a conduit to the global art market. As a source of income and jobs, but being dependent on government support. As centres of community activity and welfare services, but being assessed on market criteria. Behind the conflicts is a fundamental challenge around the development of remote Indigenous communities which leads to consideration of the suitability of Altman's hybrid economy model as a way of distilling the different pressures and expectations that are to be found in art centres.

The following section provides background information on remote art centres. Then follows a discussion of art centres and their links to regional development. Following is a consideration of the importance of local participation in the art centre model in remote regions. This leads to a discussion of art centres and the normalisation agenda, and their conceptualization through the hybrid economy model. The final sections discuss the position of intrinsic values in art centres and considers the views of government and their agencies about the role and future of remote art centres.

\section{BACKGROUND: REMOTE ARTS CENTRES AND THE HYBRID ECONOMY}

Historically, many of the remote art centres have been agents of change, offering a conduit between the market and remote communities and, in the process, redefining customary exchange practices with the introduction of monetary systems of value for cultural product. Aboriginal and Torres Strait Islander people mostly negotiated (not always easily) these changes to their local economies as part of a dynamic cultural exchange (Kimber, 1995). Within the international development literature, it is now accepted that solutions to local development cannot be designed and delivered from the top down, and that for development strategies to avoid the pitfalls of colonialism and be effective they must reflect the aspirations and be fully understood by the communities they seek to change (Sen, 2005). This may entail changing or reconsidering the terms of reference, including the development models on which they are based and the setting of goals and outcomes (Klein, 2015). Within this context, how art centres are defined and what they are expected to deliver has largely been fashioned in reference to traditional definitions of economic success and broader debates about the place of Aboriginal and Torres Strait Islander people within mainstream society (Gulliver, 2015). 
A growing contingent of academic researchers are exploring alternative economic models in order to better understand what small Aboriginal and Torres Strait Islander businesses such as art centres represent to their members and local economies and how their means of operation can reshape the way success is defined according to the distinctive modes of social and economic activity within remote communities (Altman, 2001; Russell, 2011; Curchin, 2013). Altman has repeatedly made reference to art centres as examples of what he calls the hybrid economy. His research has highlighted the role of the customary domain in the creation of much Aboriginal and Torres Strait Islander art, which draws from cultural knowledge for its form and content and derives its value within the fine art market as a marker of an authentic other (Errington, 1998). Customary practices also play a role in determining how Aboriginal and Torres Strait Islander people engage with their art centres and the broader art market (Altman, 2001, 2005a). Altman argues that art centres are 'both intercultural and hybrid' and have grown in number and profile alongside a range of associated public and private institutions (Altman, 2007: 43).

Altman (2007) regards the state, market and customary domains as interlinked, and in the case of art centres they are intrinsically dependent upon each other. The transformation of artworks, with locally determined customary value, into products of value within a global market is subsidised by government through funding for art centres. Most art centres could not continue to operate without government funding and support; they rely on the market for sales (and in turn the market relies on art centres to provide traditional art works), and without the realm of the customary, one of the key sources of creativity and distinguishing characteristics of Aboriginal and Torres Strait Islander art in the market would be lost. This codependence is a factor that needs to be taken into consideration when evaluating art centres within a community context and locates customary practices and knowledge at the centre of the economic and policy discussions around models and funding supporting local development.

Altman's hybrid economy is also potentially a process of interaction and progression as well as a defined realm of economic activity. The interactions between the state, the market and the customary domain are not static. All three domains are now markedly different to what they were in the 1970s, and each domain has impacted on the other and coalesced in the establishment of the art centres in historically specific ways

\section{ART CENTRES, DEVELOPMENT, IDENTITY AND COMMUNITY}

Definitions of development by government and NGOs, when applied to a disadvantaged component of the population, tend to assume that disadvantage can be objectively benchmarked in terms of statistical deficits in such areas as personal wealth, employment, health and education, and that the categorisation of these people as a group is validated by this evidence (Pholi, Black, \& Richards, 2009; Rowse, 2010). That the notion of disadvantaged people is as much a creation of discourse as empirical experience has become a matter of discussion as researchers give accounts of how government policies and programmes, driven by externally imposed social and cultural assumptions, impose new orders and idioms on Aboriginal and Torres Strait Islander peoples. These impact on what Rowse (2012) calls the politics of recognition and he argues that as a population, Aboriginal and Torres Strait Islander peoples can be subsumed under broader notions of equality that subordinate difference and relate to how Aboriginal and Torres Strait Islander peoples are conceptualised and how their rights are acknowledged as part of a social justice agenda.

Aboriginal and Torres Strait Islander peoples residing in remote communities offer another, more specific and discrete category of people available for scrutiny and analysis in public discourse, and their liminal location in settled Australia - both geographically and in the political imagination - allows them to be conceived as both apart from and part of Australian civic society (Rowse, 2012; Sanders, 2013). This dichotomy was reinforced by denying Aboriginal and Torres Strait Islander peoples the 
rights of citizenship and not counting them as part of the general Australian population until the 1960s (Perkins, Langton, \& Atkinson, 2008). In more recent times and within this interstitial conceptual space, Aboriginal and Torres Strait Islander peoples have become part of a political and social problem to be addressed by state and federal development strategies such as Closing the Gap and through the work of Aboriginal and Torres Strait Islander NGOs. They also become available for management through external development and philanthropic agencies (Mission Australia, Oxfam and World Vision) because of their perceived commonalities with peoples of the Third World across the globe.

Typical of the Aboriginal and Torres Strait Islander development sector is government's reliance on external organisations such as art centres to deliver services and improve community capacity building. Over the past 20 years, government has increasingly used a purchaser-provider model to fund organisations, including Aboriginal and Torres Strait Islander art centres (Australian Institute of Health and Welfare, 2000). This funding approach has dominated in the health and social services fields and presupposed that government could buy specific programmes or projects from an administering service provider, thereby outsourcing service delivery, reducing costs and increasing competition in the private sector. One of the issues with this model is how services and their costs are defined, often resulting in an underresourcing of organisations because their funding is based on what government has available to spend, rather than on the actual costs of delivery (Australian Council of Social Service, 2014).

The development role of the Aboriginal and Torres Strait Islander NGOs is undervalued and therefore underresourced but this model unlikely to be replaced with another model of delivery (Holcombe \& Sullivan, 2012). As a result, Aboriginal and Torres Strait Islander organisations frequently attempt to deliver services for which they are not funded and are therefore considered to be high risk in terms of meeting contract requirements. In turn, this leads to an overemphasis by government on management dysfunction and inefficiencies among Aboriginal and Torres Strait Islander NGOs and in turn justifies a political shift away from viewing them as key drivers and deliverers of services into remote communities (Swansson, 2010).

In the case of art centres, government arts agencies broadly support professional artists, art sales, marketing and employment. Government language in art centre contracts is often vague about what is being purchased, and there is an emphasis on partially funding projects and operational costs, rather than looking at organisations holistically. Some grant sources such as the Indigenous Employment Initiative (IEI) programme are part of the broader normalisation regime in remote communities and can conflict with some of the central tenets of art centres. In this context, art centres are upholders of cultural values and practices, while at the same time being used as agents of change in order to increase the engagement of Aboriginal and Torres Strait Islander people in the mainstream economy (Australian Government, 2013). With external pressure to contribute to the normalisation agenda, selfdetermination and local governance have remained critical issues for art centres, because from a community perspective one of their key roles is to celebrate difference and strengthen local identities. In the 1990s and early 2000s, artists were the largest contributors to art centre funding; as a result, there was a strong sense of local ownership and control (Altman, 2006). In the larger and more successful art centres this remains the case; however, for the majority of smaller art centres an increased reliance on government funding has reduced their independence and weakened their ability to set local agendas. In these instances, self-determined development is in danger of being replaced with externally and remote directed development. A case in point is the impact of the IEI programme on smaller art centres who devote increasing amounts of time to the management and administration of the arts workers funded through this programme at the expense of developing better artistic and cultural programmes.

Art centres are part of the broader Aboriginal and Torres Strait Islander not-for-profit sector, which in turn is a subset of the third sector that is made up of collectives and membership-based institutions with a community development and advocacy focus (Lyons, 2001; Rowse, 2005; Holcombe \& Sullivan, 2012). According to Lyons (2001), these types of organisations and associations are different 
from the first (state) and second (for-profit business) sectors and are typified in part by their heavy reliance on government funding and the fact that they do not distribute profits to shareholders. These characteristics define how art centres operate, as their institutional structure in many cases determines that a group rather than individuals will benefit; that income will be reinvested back into the business rather than be distributed as profit; and that this money will be used to provide some benefit to the membership. In other words, art centres are administratively set up for development; they plan and make decisions based not exclusively on financial imperatives, but primarily on community benefit outcomes.

Art centres were envisaged as an alternative to welfare dependence and as vehicles for meaningful activities and employment generation in remote communities (Wright, 1999). Arguably, many art centres had a welfare focus until well into the 1990s, when the aesthetic value of the artworks was increasingly recognised by curators, critics and collectors (Smith, 2008). While government-funded art centres were seen as a stage in the process towards financial independence and business success (Senate Standing Committee on Environment, Communications, Information Technology and the Arts, 2007: xii), very few have achieved that goal, despite having been foundational players in the development of the Aboriginal and Torres Strait Islander art market and in the contemporary art movement. Art centre advocates, including the peak agencies, have for decades argued that this development role was open-ended and that in order to positively impact on the whole community over time, art centres needed to be seen in terms of long-term development and investment (Wright, 1999; ANKAAA, 2006). Even the larger and more successful art centres maintain their development focus (Shepherd \& Acker, 2011), and the nature of the art market - with its tiers of established, emerging and trainee artists - means that art centres are always engaging with new artists, particularly as the more senior and established artists pass away. This process of regeneration and development requires ongoing investments and a long-term planning perspective.

If not-for-profit organisations are vehicles through which Aboriginal and Torres Strait Islander peoples are represented in the polity (Rowse, 2005; Sullivan, 2010), then art centres can be seen as providing an important platform for civic engagement as well as business opportunities and employment, even though they are not in any sense the complete answer to issues of deprivation and inequality in communities. There is an incongruity here. By investing in art centres, government seeks to provide an alternative to welfare reliance, even though artists often rely on income from both art sales and welfare benefits.

\section{ART CENTRES AND DEVELOPMENT MODELS}

While the dominance of neoliberalism in policy development with its emphasis on market provision and competition supported by small government and enforced property rights and regulations is widely accepted, it has not remained unchallenged (Henry, 2007; Altman, 2009). A major criticism of neoliberal policy settings is the resultant inequalities between First World and Third World people and between the colonisers and the colonised. One of the responses to these inequalities in Australia has been the development of normalisation approaches, including the facilitated engagement of Aboriginal and Torres Strait Islander peoples in global and national economies through government interventions. At the same time, and within the First World international context, remote-dwelling Indigenous people and their cultural knowledge and products have been increasingly positioned as external to the global economy, despite indicators that through local commercial enterprises such as art centres, improved native title rights and their negotiations with the resource sector, local communities are becoming increasingly engaged with the global economy.

The relative value of different modes of development in the art centre context needs to be deconstructed. In the broadest terms, development refers to social, health, education, economic and 
cultural factors, and is reflected in the broad scope of activities undertaken by relief organisations with a development focus (Howitt, Colyer, Hammer, Havnen, Huchendorf, \& Hubert, 2014). The relationship of art centres to health and social development is largely accepted, and discussions mainly revolve around how to measure these impacts (Cooper, Bahn, \& Giles, 2012). The relationship between the concepts of cultural and economic development in the discourse about art centres and the arts in general, however, is fiercely debated; the two are rarely seen as compatible. Throsby's (1995) articulation of culturally sustainable development is useful, because it proposes that neither cultural nor economic goals have primacy when thinking about the advancement of the material and nonmaterial well-being of society across generations, and as such cultural capital is prized equally to financial capital in the achievement of development goals. He goes on to suggest that this type of systems analysis (Miser \& Quade, 1985) could provide an evaluation framework for future government policies and programmes by posing questions about cultural and financial capital and what intergenerational benefits are achieved (Throsby, 1995). More importantly, it offers a perspective on cultural development not just as an exercise of elitism, but as a core and essential part of a society's development as a whole.

If art centres are seen from the perspective of sustainable cultural development rather than as economic development organisations per se, they can be allowed to focus on what they do most effectively: increase cross-generational cultural capital rather than function as tools to achieve a broader normalisation strategy. The alternative is to push or encourage them into a broader development role that they are poorly equipped and placed to deliver. Art centres are to a degree complicit in this problem, as many do behave like development agencies in an environment where many of the basic social services and infrastructure supports are absent.

\section{ART CENTRES AND LOCAL PARTICIPATION AND ENGAGEMENT}

International interest in remote community Aboriginal and Torres Strait Islander art has made it a valued tool for cultural diplomacy and kept political interest in the debates about Indigenous people and remote communities alive in world development forums as well as in art and anthropological circles. Artists are both revered as practitioners of arcane and elusive art forms that conjure up the real Australia and confirm their status as first peoples, as well as marginalised and excluded from the market networks of dealers and collectors (Australia Council for the Arts, 2006).

While Aboriginal and Torres Strait Islander artists and their artwork are fundamental to the arts sector, most associated art businesses, including art centres representing remote community artists, are owned or managed by non-Aboriginal and Torres Strait Islander people (Woodhead, 2014). Through decades of government subsidisation of the art centres and the Aboriginal and Torres Strait Islander art market, an extensive and now established network of commercial galleries, auction houses and retail outlets has emerged, as part of the downstream multiplier effect (Acker, 2014). This secondary market sector is much larger in scale than the art centre network, yet it is largely ignored by government analysts and statisticians in terms of the evaluation of the Indigenous art market.

Aboriginal and Torres Strait Islander people are arguably not the main financial beneficiaries of the broader art market, with most of the positive outcomes for artists and communities being reflected in their local economies and in the political/cultural platform their artwork has provided (Acker, 2014). The Aboriginal and Torres Strait Islander art market, as all art markets, trades in signs and symbols; artists are positioned as holders of ancient knowledges with powerful connections to remote and exotic locations rather than as commercial agents dependent on the sale of their artwork.

Aboriginal and Torres Strait Islander art centres are remarkable examples of enterprises that operate within both the commercial constraints of regional and remote communities and, to varying degrees, as part of a global art market (Acker, 2014). As part of regional and remote Australia's economy, art 
centres are subject to the same political, logistical, social and economic pressures that have been well described within the literature (Ingamells, Holcombe, \& Buultjens, 2011; Rola-Rubzen, Gibbs, Gabunada, Burritt, Altangerel, Rubzen, \& Carter, 2011).

History tells us that regional and remote development policies are developed in urban political centres, away from the small communities they are seeking to support or change. While other countries in the developed world have found a place for local economic growth strategies, whether they be driven by the private or the public sector, there continues to be debate in Australia over whether resources should be devoted to regional and remote initiatives in preference to the large-scale and generalised national interventions that now dominate the political landscape (Beer, 1998; Walker, Porter, \& Marsh, 2012). This value-for-money approach to supporting outlying communities has been particularly targeted at Aboriginal and Torres Strait Islander people and has been encapsulated in former Prime Minister Abbott's statements that Australia cannot afford the lifestyle choices of Aboriginal and Torres Strait Islander peoples living in economically unviable communities (Medhora, 2015).

Attempts have been made to address issues of economic marginalisation through the support of networks such as Supply Nation (2015) and the introduction of procurement thresholds for services and supplies to be sourced through Aboriginal and Torres Strait Islander businesses. For most Aboriginal and Torres Strait Islander people living in remote Australia, however, these initiatives have had little impact; most gain their business experience through the negotiation of land-use agreements and the development of small local enterprises. These businesses are characterised by their local sphere of operations, the employment or engagement of primarily community members and their focus on economic opportunities specific to their location, whether it be agricultural, pastoral or, in the case of art centres, cultural.

Development policies in Australia have primarily prioritised national prosperity and the global economy over local economies (Ingamells, Holcombe, \& Buultjens, 2011). In an attempt to address the spatial inequities and consequences of national economic restructuring on regional communities, state and local governments became active in the 1980s and 1990s with the aim of stimulating local economic development (Beer, 1998). However, infrastructure and services in regional and remote Australia have been distributed unequally and have been inadequate, even in places where more permanent economic development is the aim (Walker, Porter, \& Marsh, 2012). The debate about how government should target its activities and funding continues to oscillate between the extremes of a national intervention and the notion of subsidiarity, where control and influence are concentrated at the community and individual level, with government only directly acting in areas beyond local capacity (Hunt \& Smith, 2007; Pearson, 2010; Ingamells, Holcombe, \& Buultjens, 2011; Walker, Porter, \& Marsh, 2012).

In the context of current debates about welfare-dependent communities and the need to develop regional economies, it is critical to understand what role small enterprises such as art centres play and how they are affected by the shifting of resources as government policies move away from selfdetermination and towards assimilation, normalisation and statistical parity (Forrest, 2014). For the majority of Aboriginal and Torres Strait Islander peoples residing in regional and remote communities, the local economy of small, often communally owned and managed organisations is the primary way that they engage with the broader economy and express their political and civic rights as well as earn a wage or generate income through their art practice or Native Title rights. Local organisations, including art centres, are often woven into the power structures of their local communities, and their governance often reflects the community's internal order (Sullivan, 2011a).

Art centres often have boards of management that reflect customary social and cultural groupings and form a powerful nexus of community ownership. These funded organisations operate as brokers, not only within the broader art market but within local exchange systems as well. In this way, art 
centres are a very particular kind of expression of what Altman calls the hybrid economy. Art centres have been successful in maintaining their relevance in communities because they are shared territories, spaces where local and mainstream economies of value can coexist. The most successful art centres have operated as extensions of the community's local economy and customary order rather than as independent for profit businesses, and communal ownership has reinforced this fluid and rarely articulated intercultural enterprise model (Acker, 2012). It is in this context that the efforts to normalise artists and communities can be seen as dismantling vibrant, productive and evolving economic relationships that have underpinned a market for decades and have permitted artists to carve out a locally valued way of life close to country both physically and metaphorically.

\section{NORMALISATION, ART CENTRES AND THE ART MARKET}

The normalisation agenda has been taken up by both the major parties in the Australian context and can be seen in publicly commissioned reports such as the Forrest Review that examined how Closing the Gap targets can be met as quickly as possible and with little regard for Aboriginal and Torres Strait Islander self-determination or agency (Forrest, 2014). Framed within a perspective in which Aboriginal and Torres Strait Islander cultural and social practices are either a problem or of no relevance, Forrest's report makes no references to art centres or to other local enterprises and recommends Aboriginal and Torres Strait Islander peoples be encouraged to move away from their commercially limited communities into larger centres where employment and training are more readily available. His plans for change are unapologetically assimilationist and justified, he argues, because of the disparities in health, education and employment. While few would deny these disparities and the need to address them, the mechanisms whereby this can be achieved are still poorly understood. Government, despite all the research indicating that local solutions and diverse strategies being adapted to specific environments and circumstances are potentially the most effective, has a poor history of developing programmes that are responsive to local needs and circumstances (Deleuze, 1987).

Forrest's report also represents a complete turnaround from the policies of the 1970s that triggered the restoration of land rights and a return to homelands and unexpectedly led to a renaissance in art production that fitted with the government's agenda of supporting economic opportunities for people living on country. While art centres are not posited as the alternative to Forrest's plan, they do highlight the polar nature of the debate that focusses on enforced change for the sake of development and positions culture, identity and customary practices as being located outside the concerns of government and peripheral to the creation of 'real' jobs, within the 'real' economy. This significantly limits the opportunity to view culture, identity and customary practices as central to remote community economies and discourages exploration of alternative economic models that might help better articulate how they function. However, there are alternatives to the assimilationist, market driven and capital city controlled development process.

\section{THE HYBRID ECONOMY MODEL OF ART CENTRES AND INDIGENOUS DEVELOPMENT}

The hybrid economy model developed by Altman demonstrating the interaction between government, the market and customary art has received attention in academic circles; however, policymakers - who are arguably the intended audience for his work - have not applied his findings to policy frameworks and programmes, possibly because of a lack of clarity about how to do so and the model's inherent contradictions with certain fundamental presumptions upon which their current policies are based (Busilacchi, Williams, Sutton, Begg, \& Russ, 2013; Curchin, 2013, 2015; Codding, Bird, \& Bird, 2015). This is certainly the case in the Aboriginal and Torres Strait Islander arts sphere, which Altman 
has used as an exemplar of his model (Altman, 2001). No arts policies at a federal or state level make use of the term hybrid economy, nor do any of the associated strategies refer to customary practice in economic terms. There are repeated mentions in these documents of the importance of cultural maintenance and vitality, but the connection is not directly made that cultural vibrancy is a foundational part of an art economy, without which artists and art centres would struggle to succeed in a very competitive marketplace (Arts Queensland, 2011; Government of Western Australia, 2012; Department of Regional Australia, Local Government, Arts and Sport - Office for the Arts, 2013).

It could be argued that the policy documents assume that art centres have a role to play in developing and sustaining cultural practices but they do not recognise that these practices are the currency in which art centres trade and thereby secure a place in the broader global economy. Where industry development is discussed, the notion of economy starts at the point of production when objects are made and sold. In this traditional interpretation of the art economy, it is external moneybased markets that need to be developed, funded and supported, not the private realm of the customary economy, which is invisible once the work leaves the hands of the artist and art centre. How to make visible the economic value of customary practices is a challenge for academics and researchers, and it is likely that the arts and landcare sectors are the clearest examples of how they financially contribute to the economy.

If it is accepted that customary practice plays a role in the economic world of Aboriginal and Torres Strait Islander peoples in regional and remote communities, then it becomes difficult to argue that Aboriginal and Torres Strait Islander peoples are not engaged, or are engaged in only a limited way, with the market economy. Altman's argument is that there is a parallel and at times intersecting economic sphere that is local and community specific, within which people exchange and create value that at times and in various forms is then exchangeable within the mainstream economy through art centres, landcare programmes and the development of industries based on traditional knowledge. Underpinning his model is the assumption that customary practices and economies are of equal significance to mainstream economies when examining how Aboriginal and Torres Strait Islander peoples exchange, consume and create value within their own communities and country. It is therefore not that Aboriginal and Torres Strait Islander people are less engaged with 'economy', but rather that they are less engaged with the mainstream market economy. Altman argues that 'important Indigenous contributions remain unquantified and not recognised in mainstream calculations of economic worth' (Altman, 2001: v). The question then becomes: How can the value of what Aboriginal and Torres Strait Islander peoples contribute to the mainstream economy - as well as the labour and learning that are involved in being part of the customary system - be recognised, costed and better understood?

Altman is seeking a major shift in thinking about remote communities. He charges government and the market with the tasks of reassessing how success in communities is defined and how customary practices can be acknowledged as a central part of local economies with potential and realised value in the broader market. Aboriginal and Torres Strait Islander agency is apparent in his model, as artists and art centres have had to respond to the pressures brought to bear by successive government administrations and by external market forces. However, in the case of hybrid economies, customary practices are conceptualised as a strength, not as a point of vulnerability open to exploitation and permitting a different set of standards to be applied to wage levels, working conditions and management from those widely accepted in the mainstream economy.

His model by no means demonises the market or the state but is rather a bid to better understand how Aboriginal and Torres Strait Islander peoples in remote communities devise and experience their economic relationships and activities. In his model, the state and the market are potentially part of the solution, provided that the dominant discourse can be changed to accept a nonmonetary and locally based definition of an economy being of equal value to a fully monetised economy and to recognise the commercial potential of Aboriginal and Torres Strait Islander customary practices and knowledge as 
expressed in caring for country and art production. In the case of art centres, this requires ongoing government investment in what he calls the 'intercultural infrastructure' that underpins the broader Aboriginal and Torres Strait Islander arts sector (Altman, 2007: 49).

From a semiotic perspective, Altman's model is highly problematic, as it utilises broad categories such as state and market as named and bounded domains that are juxtaposed with the customary domain. Similarly, the positioning of the customary as an entity is also counterintuitive when viewed within the context of anthropological debates about structuralism and the difficulty in sustaining closed system approaches to cultural studies and intercultural relationships (Bourdieu, 2000; Merlan, 2005). Altman's customary domain reduces the complexity and multipositional nature of cultural experience and would seem to suggest that there is a foundational difference between customary practices and the contemporary world of the state and market. Each of his three categories refer to patterns of production and are populated by people, hierarchies and institutions. As such, they are defined by multiple layers of social behaviours as well as socially constructed systems of order. Using art centres as case studies makes this all the more apparent and calls into question the usefulness of the model in deconstructing programmes of normalisation and as an alternative to more traditional definitions of the economy.

In many of his early articles about the hybrid economy and its applications to economic futures in remote and very remote Australia, Altman has the state positioned at the top of the model and represented as being the largest domain. From this dominating position, the state would seem to override the influences and impact of the customary and market; this reflected Altman's suspicion that the state was indeed the major enabling/disabling factor or agent for communities (Altman, 2005b). In later versions of his papers, the state domain was positioned as equivalent in size to the two other sectors, marking another shift in his thinking and a growing concentration on the nexus between the market and customary practices and knowledge (Altman, 2009).

So how does Altman see art centres as an embodiment of his hybrid economy model? The model arose from a mix of anthropological and economic discourses and can confusingly be used to describe both Aboriginal and Torres Strait Islander peoples in remote communities and how they engage with each domain in the course of their day-to-day lives, but also more specifically to describe organisations such as art centres, which in his thinking somehow embody all three states within the one operational practice. He shifts between the two concepts without comment in his writings, never articulating what the differences are between the model as experienced by individuals and the model as expressed through an organisation like an art centre that embodies its fundamentals.

In Figure 1, some of the characteristics of each of the domains are outlined as they relate to art centres. The State, which in his earlier work Altman (2001) set as the dominant stakeholder in remote communities, both defines Aboriginal and Torres Strait Islander people and communities as in need of support and provides this support in very particular focussed and politicised ways. The customary realm provides the product and context for the artwork and is sustained by ongoing connections to country. The market attributes its own set of monetary values and provides a pathway through which artworks accrue value as they journey from communities to galleries, auction houses and the hands of private collectors.

Curchin $(2013,2015)$ has argued that the hybrid economy offers an alternative to mainstream economy behaviours (such as set work hours) and permits a more flexible approach to how people can be supported to manage their paid work and their familial and cultural obligations. While some art centres do in this sense provide a hybrid economy approach to employment, there is growing pressure from government to be less flexible and to have set work hours for all funded employees (Curchin, 2015). This mismatch in expectations has led to many Remote Jobs and Communities Programme and IEI positions being part-time rather than full-time. There is also a danger that these arguments may seem reductionist, reflecting work/life balance debates occurring across the First World economies and focussing on a symptom of the clash between values rather than as a process that maps systemic change. 


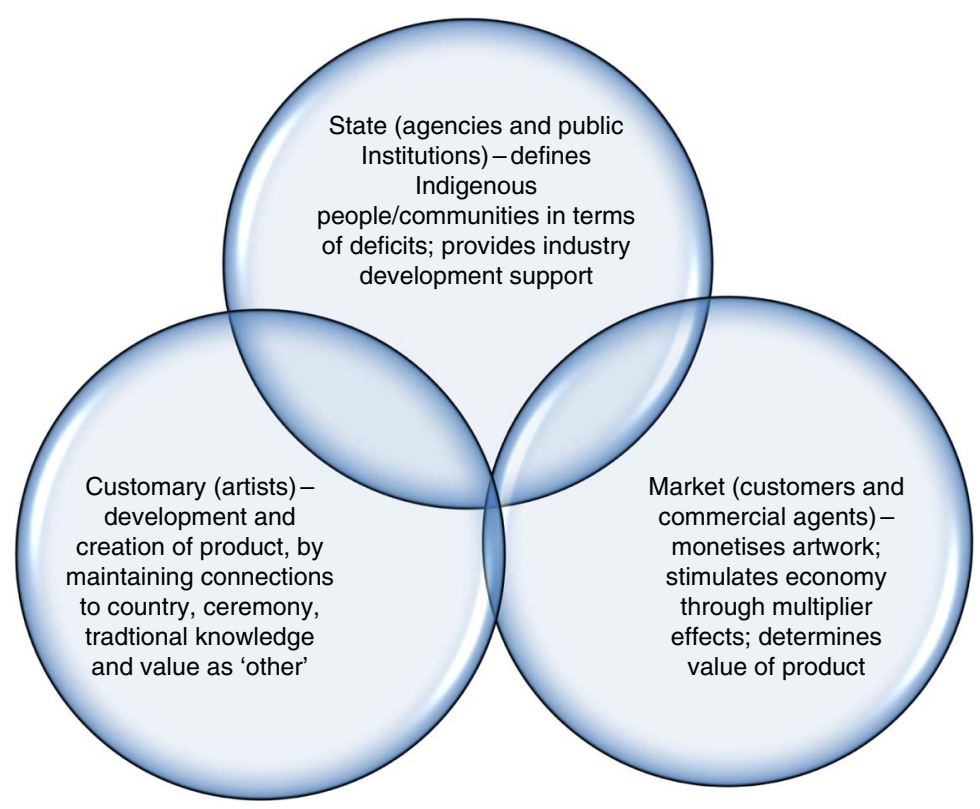

Figure 1. Art Centres and the hybrid economy. Congreve (2016) based on Altman (2005B)

If the model is applied from the point of view of an artist or individual, the art centre becomes the representative of the market and state and, at times, the customary (depending on the projects and cultural activities it hosts). The art centre, from this perspective, can be better described as a hybrid business rather than a part of a hybrid economy, and the possibility arises that Altman's model can only be applied to a very limited range of enterprise types. The characteristics of these businesses would be that they exist in commercially marginalised environments because of state funding, they rely on the customary domain for product, and they broker the transition of customary-based labour into the monetised economy. When operating in a hybrid way, art centres as publicly funded cultural businesses appear to be commensurate with Aboriginal and Torres Strait Islander world views, art market demands and government expectations. They are regarded by artists as of value, not only because of the money they generate, but also because of the cultural authority they project in both the market and government settings (Martumili Artists, 2008).

The hybrid economy model does not stipulate how active or widespread customary activities need to be in order to be considered economically relevant; rather, it seeks to highlight the existence of these practices and their interrelationship with business and the state. Altman's definition of customary practice embraces both subsistence and cultural activities, and his research is supported by a small but growing body of statistics collected through the National Aboriginal and Torres Strait Islander Survey, which shows that in remote communities many of the adult population are hunting and fishing and do participate in paid or nonpaid cultural activities (Busilacchi et al., 2013). The lack of longitudinal and detailed subsistence economy data is evident across the country and means that the dynamic interplay between customary livelihood practices and the mainstream economy is poorly documented (Altman, 2000) and this represents one of the major limitations to applying Altman's model.

Altman's pragmatic approach to Aboriginal and Torres Strait Islander economic development through landcare projects and art centres limits his model to being an exemplar of the instrumental and monetary outcomes that could arise if Aboriginal and Torres Strait Islander contributions and expertise 
were valued economically, although he recognises that they are not a panacea for disadvantage, as the opportunities for employment and income generation in remote communities are limited (Altman, 2009).

\section{ART CENTRES AND THEIR SUPPORT OF INTRINSIC VALUES}

Art Centres have a pivotal role in the practice of culture and the recording of culture (Desart, 2006: 10). The intrinsic value of Aboriginal and Torres Strait Islander art has remained strongly in the minds of not only artists but also the state and market, which have a vested interest in seeing the art industry succeed. Fortuitously, the art has been coopted into the art market because of its aesthetics and exotic cultural value. Statements by Aboriginal and Torres Strait Islander artists about the importance of culture abound, and Desart - the peak agency for Central Australian art centres - has as its tagline 'Culture First' to reinforce its message that its art centre members help to support and sustain a living cultural heritage. Art centres have an intrinsic value for artists and their communities as institutions for cultural maintenance and expression. Many art centres have their own community collections of artworks, held in trust for future generations, and a role to play in supporting ceremonies by assisting with logistics, money, storing objects or providing a space for meetings and performances (Acker, 2012). In the eyes of many artists, these activities are part of the logic behind having an art centre and are complementary to their commercial functions (Acker and Congreve, 2016).

While ultimately much of the artwork produced in art centres is destined for sale, the designs, forms and stories are part of a highly valued and culturally complex, and they give corporeal form to customary beliefs (Morphy, 1991, 2008). Increasing attention has been paid to examining the value of Aboriginal and Torres Strait Islander art in the eyes of the artists and/or their community and that of the customer or audience (Coleman, 2005; Van Den Bosch \& Rentschler, 2009).

Curchin has argued that Aboriginal and Torres Strait Islander art in this context has been only partially commodified because its value is not completely defined by the market, and that across many sectors of society one of the main strategies to avoid the full commodification of products and services is to apply to government for funding (Curchin, 2015). In this sense, government funding partially shields the Aboriginal and Torres Strait Islander art centres from the full force of the market and allows for nonmarket activities and values to be part of remote art centres' spheres of activity. The fact that these are areas that have long been valued by the cultural sector as a whole and that to some degree modalities of funding delivery have been developed within bodies like the Australia Council to account for this has helped the Aboriginal and Torres Strait Islander art centres navigate between industryfocussed and arts-focussed programmes in order to achieve both commercial and cultural goals (Australia Council for the Arts, 2014).

\section{GOVERNMENT AND ART CENTRES}

Many art centres and artists subsidise other support services for their communities such as nutrition, numeracy and literacy, training and employment, leadership, youth services and after school holiday programmes, as well as facilitating access to government services (Australian Government, 2013: 1). While art centre representatives have for decades tried to convince government of the auxiliary responsibilities set by communities in the hope that this would permit a more coherent and responsive policy position, instead this appears to have resulted in an expectation that art centres will contribute to community well-being without public subsidy (Wright \& Morphy, 2000). The positive association of cultural retention and participation is now well documented, and the links between culture and economic development - particularly in the burgeoning creative industries - are widely accepted, but 
TABle 1. Comparison of government AND ART CENTRE PRIORITIES

\section{Art centre}

Government

Are customary practices part of the solution or part of the problem for Aboriginal and Torres Strait Islander disadvantage?

Are communities, outstations and homelands commercially and financially viable? Should government fund this?

How to reduce the economic, social and cultural differences between Aboriginal and Torres Strait Islander and nonAboriginal and Torres Strait Islander people?

How to generate income through art production to How to support people into mainstream work and towards commercial centres?

How to encourage and support Western work practices and attitudes?

balance this with customary obligations?

How can Aboriginal and Torres Strait Islander people access the same level of services as non-Aboriginal and Torres Strait Islander people?

Source. Congreve (2016).

there are also other more practical and tangible ways in which art centres are considered to serve communities (UNCTAD, 2008; Dockery, 2010).

Art centres have become a means for government to ameliorate the impact of minimal staffing and service provision in communities. Aboriginal and Torres Strait Islander organisations such as art centres have therefore become implicated in the challenges of economic and social disadvantage within the Closing the Gap context and are measured against these standards. Art centres are expected to directly improve school attendance, community health, education and economic development as well as function as business and cultural enterprises. As a result, there is a gap between what governments expect and what art centres have the capacity to achieve. Art centres are also positioned as agents of change in ways that are not always commensurate with community aspirations and are not articulated explicitly in policy and programme documentation. The assignment of expectations occurs at a much earlier and higher level of policy and programme development, when overarching goals and approaches are confirmed and committed to. How goals and issues are defined as part of the policy development process has come in for regular criticism from researchers and activists, who emphasise that solutions can only be developed from the ground up and in response to localised agendas and needs (Beer, 1998; Mowbray, 2006; Brueckner, Pearson, Chatterjee, Wise, \& Marika, 2011). In this way, the agendas for art centres diverge, leading to different questions being posed and strategies being suggested. Table 1 summarises some of the key differences between the priorities of the state and those of remote communities with respect to the role of arts centres.

A distinction needs to be made here about how art centres are defined within policy and programme documents and how they are regarded by government staff. The majority of key government staff working directly with art centres have a benign attitude and nuanced understanding of the multifaceted role played by art centres. They are very aware that policy and programme documentation could be very one-dimensional and do not reflect the complexity of art centres. Staff also recognised the need for whole-of-government approaches to funding for art centres, an aspect that is not reflected in current programme documentation on a state or federal level, although it was recognised as critical in both the 1989 report into arts and crafts (Altman, 1989) and submissions to the 2007 Senate Inquiry (2007). 


\section{CONCLUSIONS}

Art centres make and attract money and are clearly part of the mainstream economy. The past 40 years have seen a rapid increase in the commodification (Bourdieu, 2000) of Aboriginal and Torres Strait Islander cultural knowledge and forms, including artwork (Mosby, 1996; Gray, 2000; Jorgensen, 2007; Rothwell, 2015). The movement towards better understanding and finding practical and commercial applications for Indigenous knowledge has occurred over the same period of time as the rise of the Aboriginal and Torres Strait Islander art industry (Ross \& Pickering, 2002; Janke \& Dawson, 2012). The interest in local knowledges and their contribution to research and innovation in industry are increasingly recognised as valuable and requiring protection (Indigenous Advisory Committee Secretariat, 2012).

However, very little research exists about what art income means for artists and how this relates to the local economy in communities. Altman's (1989) report attempted to calculate art centre income as a proportion of the total income of communities; such a comparative study if applied today could provide an insight into the economic impact of art centres on local economies. According to estimates, artists have earned more than \$94 million dollars in the period between 1990/1991 and 2012/2013, and art centre sales have been almost $\$ 160$ million (Acker \& Woodhead, 2014b: 23).

Art centres also save government money through their substantial nonfinancial contributions, or positive externalities through local service provision, often by voluntary labour. The value of these savings is almost impossible to calculate but is reflected in the underspend on services to Aboriginal and Torres Strait Islander people across the country and by all areas of government activity (Havnen, 2012; Howitt et al., 2014).

Closing the gap reports (Australian Government, 2014, 2015) emphasise funding art centres as agents of change in remote communities and capitalises on their capacity to positively represent cultural difference and strengthen local identities. Their legal structure is administratively set up to provide Aboriginal and Torres Strait Islander people with a voice and to direct art centre activities and income to the benefit of their communities. They provide an important platform for civic engagement and local leadership. In this sense, art centres play an important development role in communities. However, these frameworks are in danger of being hijacked by government to achieve programme goals of normalisation and mainstream economic engagement.

Development in this context refers not only to increased engagement of Aboriginal and Torres Strait Islander people in the market economy but also to their role as innovators in the market. Great artists are not simply discovered; they require support and training and the keen eye of art specialists who can recognise outstanding talent. In order to secure their own future financial relevance in the community, art centres must work with emerging artists or carry the risk of having only a handful of artists, if any, experience market success. Commercial galleries are reluctant or unable to take on this level of risk and depend on the art centres to do this development work on their behalf. In this sense, art centres are part of the research and innovation component of the industry and have met the market's demand for new artists and art forms for decades.

Art centres are not limited to being tools for development but are also businesses with their own commercial networks and professional standards. They are, however, primarily cultural development organisations. Their roles as mentors to new and emerging artists and trustees of local cultural knowledge and expression are central to their aims. These roles are valued by the community. Rather than being pushed into a broader development role that they are not funded for and do not have the capacity to deliver, art centres may do better if they are allowed to focus on the development of their local economies and the political/cultural platform their artwork has provided.

Art centres are remarkable in that they have operated within the challenging commercial environment of remote Australia with a measure of success and in some cases for more than 40 years. While they have connected artists and arts workers to the national and global art world, their local sphere of operations and there contribution to local communities is just as important and is shaped by the 
general shortfalls in infrastructure and services in remote communities. While they have become embroiled in the neoliberal aspects of the Closing the Gap agendas, they are successful and relevant in communities because they are spaces where local and mainstream economies of value can coexist, albeit in a dynamic state of flux.

\section{ACKNOWLEDGEMENT}

This research was supported by CRC-REP Ninti One. The authors acknowledge the important contributions of Michael Dockery and Tim Acker.

\section{References}

Acker, T. (2012). The Art of Community: the place of art centres in the Ngaanyatjarra Lands. In T. Acker \& J. Carty (Eds.), Ngaanyatjarra: Art of the lands (pp. 37-47). Perth: UWA Publishing.

Acker, T. (2014). Aboriginal and Torres Strait Islander art and its place in the global art market. In C. A. L. Pearson, J. Burgess, \& K. Dayaram (Eds.), Australian Indigenous employability education and entrepreneurship: Exploring the issues in a compendium of case studies (pp. 87-101). Singapore: Booksmith.

Acker, T., \& Congreve, S. (2016). Desert perspectives - Aboriginal arts workers in remote art centres (Vol. CR013). Alice Springs: Ninti One Limited.

Acker, T., \& Woodhead, A. (2014a). The art economies value chain reports: Artists and art centre production (Vol. CR007). Alice Springs: Ninti One Limited.

Acker, T., \& Woodhead, A. (2014b). The art economies value chain reports: Art centre finances (Vol. CR006). Alice Springs: Ninti One Limited.

Altman, J. (1989). The Aboriginal arts and crafts industry: Report of the review committee. Canberra: Australian Government. Altman, J. (2000). The economic status of Indigenous Australians Paper 93/2000. Centre for Aboriginal Economic Policy Research, ANU, Canberra.

Altman, J. (2001). Sustainable development options on Aboriginal land: The hybrid economy in the twenty-first century (Vol. 226). Canberra: CAEPR, Australian National University.

Altman, J. (2005a). Brokering Aboriginal art: A critical perspective on marketing, institutions, and the state (Lecture). Melbourne: Deakin University.

Altman, J. (2005b). Economic futures on Aboriginal land in remote and very remote Australia: Hybrid economies and joint ventures. In D. Austin-Broos \& G. Macdonald (Eds.), Culture, economy and government (pp. 121-134). Sydney.

Altman, J. (2006). The Indigenous hybrid economy: A realistic sustainable option for remote communities? (Vol. 2). Canberra: CAEPR, Australian National University.

Altman, J. (2007). Alleviating poverty in remote Indigenous Australia: The role of the hybrid economy. Development Bulletin, 72, 47-51.

Altman, J. (2009). The hybrid economy and anthropological engagements with policy discourse: A brief reflection 1. Australian Journal of Anthropology, 20(3), 318-329. http://dx.doi.org/10.1111/j.1757-6547.2009.00039.x

Altman, J. (2012). The Aboriginal arts economy in the centre: Marketing and policy challenges. In M. Culpitt (Ed.), Change your life, manage the desert: The Desart art centre guidebook (pp. 82-83). Desart: Alice Springs.

Altman, J. (2013). The escalating challenges of doing Indigenous arts business in remote Australia in the 21st century. Presented at the Research Exchange 2013: Remote Indigenous Enterprises in Arts and Tourism, Canberra, ACT.

ANKAAA (2006). Submission to the senate environment, communications, information technology and the Arts Committee Inquiry into Australia's Indigenous visual arts and crafts sector. Darwin: ANKAAA.

Arts Queensland (2011). Backing Indigenous arts: Evaluation report. Brisbane: Queensland Government.

Australia Council for the Arts (2006). Submission by the Australia council to the senate inquiry into the Indigenous visual arts and craft sector. Sydney: Australia Council.

Australia Council for the Arts (2014). Artistic vibrancy e-book: A way for organisations to talk about artistic impact. Sydney: Australian Government.

Australian Council of Social Service (2014). Submission from the Councils of Social Service in Australia to the national competition policy review. Retrieved June 10, 2015, from http://competitionpolicyreview.gov.au/files/2014/12/ JCOSS.pdf. 
Australian Government (2013). Indigenous art centre plan. Canberra: Australian Government.

Australian Government (2014). Closing the gap: Prime Minister's report 2014. Canberra: Australian Government.

Australian Government (2015). Closing the gap: Prime Minister's report 2015. Canberra: Australian Government.

Australian Institute of Health and Welfare (2000). Integrating indicators: Theory and practice in the disability services field. Canberra: Australian Government.

Beckett, J. (1987). Torres Strait Islanders: Custom and colonialism. Cambridge: Cambridge University Press.

Beer, A. (1998). Economic rationalism and the decline of local economic development in Australia. Local Economy, 13(1), 51-63. http://dx.doi.org/10.1080/02690949808726422

Blagg, H. (2008). Crime, Aboriginality and the decolonisation of justice. Annandale, NSW: Hawkins Press.

Bourdieu, P. (2000). Pascalian meditations (R. Nice, Trans.). Oxford: Polity Press in Association with Blackwells.

Brueckner, M., Pearson, C., Chatterjee, S., Wise, G., \& Marika, B. (2011). Indigenous entrepreneurship: Closing the gap on local terms. The 12th International Conference of the Society for Global Business \& Economic Development, 21 July, Society for Global Business \& Economic Development (SGBED), Singapore, pp. 1820-1829.

Busilacchi, S., Williams, A. J., Sutton, S. G., Begg, G. A., \& Russ, G. R. (2013). The role of subsistence fishing in the hybrid economy of an Indigenous community. Marine Policy, 37(1), 183-191. http://dx.doi.org/10.1016/j. marpol.2012.04.017

Codding, B. F., Bird, D. W., \& Bird, R. B. (2015). The real cost of closing remote communities. Arena Magazine, 135, $5-7$.

Coleman, E. B. (2005). Aboriginal art, identity, and appropriation. Aldershot, Hants, England: Ashgate.

Congreve, S. (2016). Investigations into the role of the enabling environment in supporting Indigenous economic development: A case study of remote community Aboriginal and Torres Strait Islander Art Centres 2007-2013. PhD dissertation. John Curtin Institute of Public Policy, Curtin University, Perth.

Cooper, T., Bahn, S., \& Giles, M. (2012). Investigating the social welfare indicators of Aboriginal regional art centres: A pilot study. Perth: Edith Cowan University.

Curchin, K. (2013). Interrogating the hybrid economy approach to Indigenous development. Australian Journal of Social Issues, 48(1), 15-34.

Curchin, K. (2015). Two visions of Indigenous economic development and cultural survival: The 'real economy' and the 'hybrid economy'. Australian Journal of Political Science, 50(3), 1-15.

Deleuze, G. (1987). A thousand plateaus: Capitalism and schizophrenia. Minneapolis, MN: University of Minnesota Press.

Department of Regional Australia, Local Government, Arts and Sport - Office for the Arts (2013). Indigenous visual arts industry support (IVAIS): Australian Government funding to strengthen the Indigenous visual arts industry. Canberra: Australian Government.

Desart (2006). Submission - Inquiry into Australia's Indigenous visual arts and craft sector. Alice Springs: Desart.

Dockery, A. M. (2010). Culture and wellbeing: The case of Indigenous Australians. Social Indicators Research, 2, 315-332. http://dx.doi.org/10.1007/s11205-010-9582-y

Errington, S. (1998). The death of authentic primitive art and other tales of progress. Berkeley, CA: University of California Press.

Escobar, A. (1995). Encountering development: The making and unmaking of the third world. Princeton, NJ: Princeton University Press.

Forrest, A. (2014). Creating parity. Canberra: Australian Government.

Government of Western Australia (2012). Indigenous arts and culture action plan 2012-2014. Perth: Government of Western Australia.

Gray, S. (2000). X-ray wallabies and Mickey Mouse: The commodification of the 'authentic' in Aboriginal art. Overland, 159, 124-126.

Gulliver, S. (2015). Neoliberal multiculturalism and indigeneity. Arena Magazine, 138, 23-27.

Havnen, O. (2012). Office of the Northern Territory Coordinator-General for remote services report, June 2011 to August 2012. Darwin: Northern Territory Government.

Hechter, M. (1975). Internal colonialism: The Celtic fringe in British national development, 1536-1966. London: Routledge and Kegan Paul.

Henry, K. (2007). Addressing extreme disadvantage through investment in capability development. Economic Round-Up, winter, 1-13. 
Holcombe, S., \& Sullivan, P. (2012). Australian Indigenous organizations. In D. Caulkins \& A. T. Jordan (Eds.), A companion to organizational anthropology (pp. 493-518). Malden: Hoboken-Wiley.

Howitt, R., Colyer, C., Hammer, M. R., Havnen, O., Huchendorf, K., \& Hubert, C. (2014). Organisational capacity for engaging with Indigenous Australians. Geographical Research, 52(3), 250-262. http://dx.doi.org/10.1111/17455871.12066

Hunt, J., \& Smith, D. E. (2007). Indigenous community governance project: Year two research findings (Vol. 36). Canberra: CAEPR, Australian National University.

Indigenous Advisory Committee Secretariat (2012). Submission Indigenous cultural and intellectual property. Canberra: Australian Government.

Ingamells, A. T., Holcombe, S., \& Buultjens, J. (2011). Economic development and remote desert settlements. Community Development Journal, 46(4), 436-457. http://dx.doi.org/10.1093/cdj/bsq012

Janke, T., \& Dawson, P. (2012). New tracks: Indigenous knowledge and cultural expression and the Australian intellectual property system. Sydney: Terry Janke and Co.

Jorgensen, D. (2007). On the realism of Aboriginal art. Journal of Australian Studies, 90, 99-106.

Kimber, R. G. (1995). Politics of the secret in contemporary Western Desert art. In C. Anderson (Ed.), Politics of the secret (Vol. 45, pp. 123-141). Sydney: Sydney University.

Klein, E. (2015). A critical review of the capability approach in Australian Indigenous policy (Vol. 102). Canberra: CAEPR, Australian National University.

Lyons, M. (2001). Third sector: The contribution of non-profit and cooperative enterprise in Australia. Sydney: Allen \& Unwin.

Martumili Artists (2008). Martumili Artists background information. Newman: Shire of East Pilbara.

Medhora, S. (2015). Remote communities are 'lifestyle choices', says Tony Abbott. The Guardian. Retrieved from http://www.theguardian.com/Australia-news/2015/mar/10/remote-communities-are-lifestyle-choices-says-tonyabbott

Merlan, F. (2005). Explorations towards intercultural accounts of socio-cultural reproduction and change. Oceania, 75(3), 167-182. http://dx.doi.org/10.1002/j.1834-4461.2005.tb02878.x

Minister for the Environment, Heritage and the Arts (2008). Australian Government responds to Senate Indigenous arts inquiry. Canberra: Australian Government.

Miser, H. J., \& Quade, E. S. (Eds.) (1985). Handbook of systems analysis: Overview of uses, procedures, applications and practice. Chichester: Wiley.

Morphy, H. (1991). Ancestral connections: Art and an Aboriginal system of knowledge. Chicago, IL: University of Chicago Press.

Morphy, H. (2008). Becoming art: Exploring cross-cultural categories. Sydney: University of New South Wales Press.

Mosby, T. B. M. (1996). An alternative to the art market: (or how to sidestep whitefella commodification of Indigenous art in the Torres Strait). Artlink, 16(4), 9-11.

Mowbray, M. (2006). Localising responsibility: The application of the Harvard project on American Indian economic development to Australia. Australian Journal of Social Issues, 41(1), 87-103.

Pearson, N. (2010). When welfarism takes over, disaster will follow. The Australian. Retrieved from http://www. theAustralian.com.au/opinion/when-welfarism-takes-over-disaster-will-follow/story-e6frg6zo-1225824862838

Perkins, R., Langton, M., \& Atkinson, W. (Eds.) (2008). First Australians: An illustrated history. Carlton: Melbourne University Publishing.

Pholi, K., Black, D., \& Richards, C. (2009). Is 'close the gap' a useful approach to improving the health and wellbeing of Indigenous Australians? Australian Review of Public Affairs, 9(2), 1-13.

Rola-Rubzen, M. F., Gibbs, J., Gabunada, F., Burritt, R., Altangerel, D., Rubzen, B., \& Carter, A. (2011). Growing businesses in the desert: Case studies of Australian desert micro, small and medium enterprises (Vol. DKCRC Report 74). Alice Springs: Ninti One Limited.

Ross, A., \& Pickering, K. (2002). The politics of reintegrating Australian Aboriginal and American Indian Indigenous knowledge into resource management: The dynamics of resource appropriation and cultural revival. An Interdisciplinary Journal, 30(2), 187-214. http://dx.doi.org/10.1023/A:1015640713250

Rothwell, N. (2015). Turning art into a commodity. The Australian. Retrieved from http://www.theaustralian. com.au/arts/visual-arts/indigenous-art-turning-a-culture-into-a-commodity/news-story/b28f4ea1210235783a6a $8 f 719 \mathrm{a} 49 \mathrm{ca} 68$ 
Rowse, T. (2005). The Indigenous sector. In D. Austin-Broos \& G. Macdonald (Eds.), Culture, economy and governance in Aboriginal Australia (pp. 207-223). Sydney: University of Sydney Press.

Rowse, T. (2010). Re-figuring 'Indigenous culture'. In J. Altman \& M. Hinkson (Eds.), Culture crisis: Anthropology and politics in Aboriginal Australia (pp. 153-178). Sydney: University of New South Wales Press.

Rowse, T. (2012). Rethinking social justice: From 'peoples' to 'populations'. Canberra: Aboriginal Studies Press.

Russell, S. (2011). The hybrid economy topic guide. Canberra: CAEPR, Australian National University.

Sanders, W. (2013). Changing agendas in Australian Indigenous policy: Federalism, competing principles and generational dynamics. Australian Journal of Public Administration, 72(2), 156-170.

Sen, A. (2005). Human rights and capabilities. Journal of Human Development, 6(2), 150-166.

Senate Standing Committee on Environment, Communications, Information Technology and the Arts (2007). Indigenous Art - Securing the future: Australia's Indigenous visual arts and crafts sector. Canberra: Australian Government.

Shepherd, P., \& Acker, T. (2011). Martumili artists business plan 2011-2013. Newman: Shire of East Pilbara.

Smith, T. (2008). Creating value between cultures: Contemporary Australian Aboriginal art. In M. Hutter \& C. D. Throsby (Eds.), Beyond price: Value in culture, economics, and the arts (pp. 23-40). Cambridge: Cambridge University Press.

Sullivan, P. (2010). The Aboriginal community sector and the effective delivery of services: Acknowledging the role of Indigenous sector organisations (Vol. DKCRC Report 73). Alice Springs: Ninti One Limited.

Sullivan, P. (2011a). The policy goal of normalisation, the national Indigenous reform agreement and Indigenous national partnership agreements (Vol. DKCRC Report 76). Alice Springs: Ninti One Limited.

Sullivan, P. (2011b). Belonging together dealing with the politics of disenchantment in Australian Indigenous affairs policy. Canberra: Aboriginal Studies Press.

Supply Nation (2015). Government procurement. Retrieved June 12, 2017, from http://www.supplynation.org.au/ resources/government_procurement/

Swansson, J. (2010). Analysing key characteristics in Indigenous corporate failure: Research paper. Canberra: Australian Government.

Throsby, D. (1995). Culture, economics and sustainability. Journal of Cultural Economics, 19(3), 199-206.

UNCTAD (2008). Creative economy report: The challenge of assessing the creative economy: Towards informed policymaking. Geneva: United Nations.

Van Den Bosch, A., \& Rentschler, R. (2009). Authorship, authenticity, and intellectual property in Australian Aboriginal art. The Journal of Arts Management, Law, and Society, 39(2), 117-131.

Walker, B. W., Porter, D. J., \& Marsh, I. (2012). Fixing the hole in Australia's heartland: How government needs to work in remote Australia. Alice Springs: Desert Knowledge Australia.

Woodhead, A. (2014). The art economies value chain reports: Art business trading practices and policy views (Vol. CR008). Alice Springs: Ninti One Limited.

Wright, F. (Ed.) (1999). The art and craft centre story: A survey of thirty-nine Aboriginal community art and craft centres in remote Australia (Vol. 1). Canberra: Aboriginal and Torres Strait Islander Corporation.

Wright, F., \& Morphy, F. (Eds.) (2000). The art and craft centre story: Summary and recommendations (Vol. 2). Canberra: Aboriginal and Torres Strait Islander Corporation. 